\title{
Megemlékezés
}

\section{FOURIER, A POLIHISZTOR}

\section{FOURIER, THE POLYMATH}

\author{
Hujter Mihály \\ a matematika tudomány kandidátusa, egyetemi docens, Budapesti Múszaki és Gazdaságtudományi Egyetem Matematika Intézet \\ hujter@math.bme.hu
}

\section{ÖSSZEFOGLALÁS}

Áttekintjük a 250 éve született Joseph Fourier életét. Megmutatjuk a szerepét az egyiptológia kialakulásában és a hővezetés elméleti alapjainak lefektetésében. Egy példa segítségével érzékeltetjük a Fourier-sorok jelentőségét. Ismertetjük Fourier tételét a polinomgyökökről. Végül felidézzük Fourier néhány híres mondását.

\section{ABSTRACT}

We review the life of Joseph Fourier born 250 years ago. We show his role in starting Egyptology and in founding the theory of heat transfer. By using an example we show the importance of Fourier series. We provide a theorem of Fourier on polynomial roots. Finally, we repeat some of Fourier's famous sayings.

Kulcsszavak: Fourier, egyiptológia, hővezetés fizikája, Fourier-analízis, polinomok, híres mondások

Keywords: Fourier, Egyptology, physics of heat transfer, Fourier analysis, polynomials, famous sayings

\section{BEVEZETÉS}

A tizenkilencedik század legvégén az első önálló vállalkozású, nem fordításon alapuló magyar nagylexikon, a Pallas Rt. Nagy Lexikona két híres Fourier nevü francia urat ismer. Akiről többet ír, az Fourier Károly Ferenc (1772-1837). Ö az, 
akiről sok szó esett már a magyar középiskolákban. Akiről a Pallas kissé kevesebbet ír, az Fourier János Babtiste József báró (1768-1830). Szerepel még a lexikonban a Fourier-féle sor címszó is: „Ha az $\mathrm{f}(x)$ függvény -p és p között véges, foly tonos, s nincs végtelenül sok szélső értéke, akkor ezen intervallumban mindig Fourier-féle sorba fejthető. De e sorba fejtés sok más esetben is helyes." Meglepő, hogy nem írja a Pallas, melyik Fourier találta ezt ki. Sejthető viszont, hogy az utóbbi, azaz az idősebbik Fourier a feltaláló, hiszen ő többek közt „,a hővezetés problémájának általános tárgyalására oly analitikai segédeszközt teremtett, mely azóta a fizikában a legnagyobb fontossággal bír és számos feladat megfejtésére szolgál".

Az egyiptológusok is ismernek egy Fourier urat. A tizenkilencedik század legelején publikált néhány alapvető jelentőségű munkát Egyiptom történelméröl, és az ő biztatására foglalkozott Jean-François Champollion a rosette-i kö szövegének megfejtésével, mely munka híres sikerhez vezetett 1822-ben. A mai egyiptológusok csodálkoznak, hogy itt nem egy harmadik Fourier úrról van szó, hanem a fent említett két Fourier egyikéről, mégpedig az utóbbiról; akit a fizikusok is és a matematikusok is maguk közé sorolnak. A jelen írás címszereplöje is ez az idősebbik Fourier, teljes születési nevén: Jean-Baptiste Joseph Fourier. A báró előnevet nem örökölte, hanem érdemeiért kapta. A leggyakoribb névváltozata: Joseph Fourier.

\section{FOURIER ÉLETÉNEK ELSŐ HÁROMNEGYEDE}

Kétszázötven éve született egy nagy múltú püspöki székhelyü, francia kisvárosban (Auxerre) egy szegény szabómester második házasságából, sokadik gyermekként, 1768. március 21-én. A korán árvaságra jutott, kiváló szellemi képességeket felmutató fiút a helyi püspök vette pártfogásba. A bencések által müködtetett, (a hatodik századi) Szent Mór nevét viselő katonai iskolába járt, és tüzértiszt szeretett volna lenni, de nem lehetett, mert nem volt nemesi származású. Ottmaradt tehát tanársegédnek a hadi iskolán; matematikát (beleértve az akkori fizikát, kémiát, geográfiát), retorikát, történelmet és filozófiát tanított.

A forradalom évei jöttek: Fourier jakobinusként részt vett a helyi forradalmi bizottmányban. A terror idején kétszer is letartóztatták, és kivégzésének már kitủzött dátuma elött csak néhány nappal megtörtént Robespierre veszte; Fourier csak ennek köszönhetően maradhatott életben. (A történelemóráinkról tudjuk, hogy mindez 1794-ben történt.)

1795-ben Fourier Párizsba került a híres Lagrange és Monge tanársegédjének. Ne feledkezzünk el az akkori Párizs harmadik nagy matematikus, fizikus, csillagász tudósáról, Laplace-ról sem. Monge professzor és Bonaparte tábornok barátsága okán Monge tanár úrral együtt Fourier is elkísérte az akkoriban még csak „kis káplár” néven csúfolt ravasz, törekvő és vakmerő tábornokot az egyiptomi 
hadjáratán. (Induláskor még nem ismerték a titkos parancsot, hogy Egyiptomot blokkolni kell az Angliát Indiával összekötő legrövidebb út átvágása céljából. Monge professzor huszonkét évvel volt idősebb Fourier tanársegédnél, Bonaparte pedig másfél évvel fiatalabb.) Az 1798. esztendőben Málta, Alexandria, Kairó elfoglalása következett, majd Felső-Egyiptomé is.

A hadtudományok szempontjából jelentős esemény a „Piramisok csatája”. A Nílus bal partján, a gízai piramisok tövében Bonaparte 25 ezres hadteste ellen Murád bég 50 ezer emberrel vonult fel. A franciáknál volt azonban a kitünő szervezettségből és a modern fegyverzetből származó előny. És itt vetette be Bonaparte tábornok először hadtörténeti jelentőségü harcászati újítását, az úgynevezett gyalogsági négyszöget. A sikeres ötlethez nyilván hozzájárultak az előző hetek hosszas beszélgetései Monge, Fourier és Bonaparte között.

A tábornok a csapatait öt darab négyzet alakú egységbe állíttatta, melyek mindegyik oldalán hat-hat sornyi gyalogság védte a középre küldött lovasságot és a hadtápot. A kvadrátok bármilyen irányba mozoghattak, eredményesen verhették vissza a mameluk lovasokat. A mamelukok táborhelyének megrohanásával teljesedett be a franciák győzelme. A menekülő török gyalogság nagy részét megölték (sőt később még a hadifoglyokat is kivégezték), a bátor mamelukokból pedig a tábornok utóbb a maga seregébe toborzott lovasokat. Ezekből az időkből való Bonaparte elhíresült riadó-kiáltása: „A szamarakat és a tudósokat középre!”

És akkoriban történt, hogy egy híres tudós (nevezetesen Monge) elöször mászta meg a gízai nagy piramist. Hogy Fourier vele mászott-e, nem tudjuk, de joggal feltételezhetjük, hogy a professzor úr mögött cipelte a mérőfelszerelést.

Egyiptom megszállása és müködtetése, a szorongatott francia sereg ellátása munícióval, abrakkal és ennivalóval nem ment könnyen. A rendkívül ügyes szervezönek bizonyuló Fourier sok adminisztratív és tudományos feladatot kapott Kairóban, és mindenben jól megállta a helyét. (Még a mamelukok vezérének legszebb és legokosabb feleségével is kiváló kapcsolatokat ápolt. Rossz, aki rosszra gondol!)

Bonaparte és Monge hazatértek (pontosabban embereiket hátrahagyva hazaszöktek) Párizsba, Fourier pedig Egyiptomban maradt. Amikor 1801-ben az angolok már teljesen bekerítették az egyiptomi franciákat, megengedték, hogy Fourier is hazatérjen. A Fourier és társai által összegyüjtött régészeti kincsek javát maguknál látták inkább „biztonságban” az angolok. (Többek közt a rosette-i kő is Londonba került.) De a rajzokat és feljegyzéseket hazavihették Fourier és életben maradt tudóstársai. (A tudósokat nemcsak az elhúzódó háborúk, hanem merényletek és járványok is alaposan megtizedelték. Maga Fourier is élete végéig szenvedett az Egyiptomban begyüjtött betegségektől.)

Az egyiptomi expedíció történetét feldolgozó, Louis Reybaud által szerkesztett tízkötetes munkából származik Fourier itt közölt fiatalkori arcképe (1. ábra). A visszatérés után Fourier még jó ideig foglalkozott egyiptológiával, de a figyelme más irányba is fordult. Grenoble városába került Isère megye prefektusának. 
A korábbi hadmérnök és hadtápos Fourier mocsarak lecsapolását és útépítéseket tervezett és szervezett. Olyan jó diplomáciai érzékkel, mindenki számára hasznos döntésekkel végezte feladatát, hogy még akkor is hivatalában maradhatott, amikor I. Napóleon császárt már Elba szigetére kényszernyugdíjazták. De amikor visszatért, Fourier jobbnak látta egy másik városkapun keresztül távozni Grenoble városából, pedig az excsászár elvárta volna, hogy régi barátja fogadja öt.

A magyar nyelv burgonya szava is áttételesen Fourier révén keletkezett. Egy hatalmas mocsaras terület lecsapolása Fourier szervezési és irányítási tevékenysége folytán sikerült. Az új termőföldbe az akkor még kevéssé is-

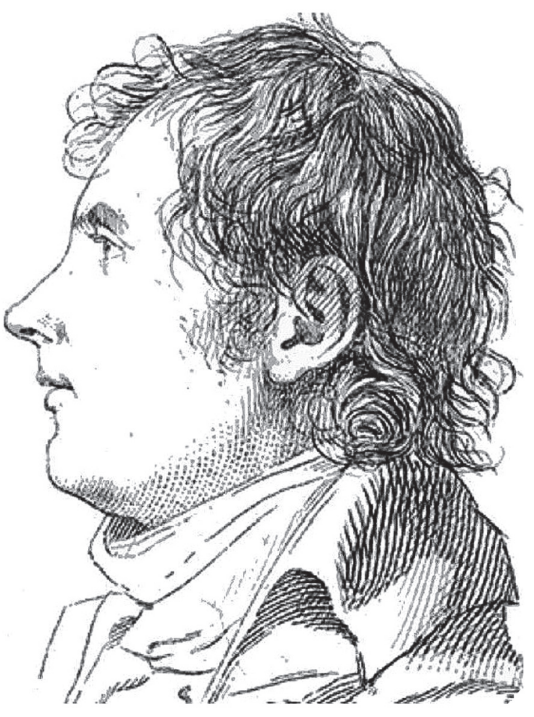

1. ábra. Fourier, „Egyiptom kormányzója” Reybaud rajzán

(URL1) mert Solanum tuberosum (azaz krumpli) került, és a termesztési sikerek révén (talán olasz közvetítéssel) a burgundiai földialma híre a burgonya változatban ért el hozzánk.

Fourier fizikai és matematikai kutatásokat is végzett ezekben az években. A hővezetésre vonatkozó Fourier-törvényt emeljük ki elsőnek. Arról van szó, hogy szilárd testekben hogyan áramlik a hő egyik helyről a másikra. Például ha egy hosszú vasrúd egyik vége már régóta fehéren izzítva van a kovács tüzében, a másik vége kiáll a levegőbe, ami körbeöleli a rudat és hủti azt, akkor valójában valamilyen hőmennyiség áramlik folyamatosan a vasrúdban az izzított végtől a hütött vég felé. A hömennyiség áramlásának intenzitása az izzított végtől $x$ távolságban egyenesen arányos azzal a hömérséklet-különbséggel, ami az $x$ távolságon megvalósul, de fordítottan arányos magával az $x$ távolsággal. Tehát 2 méter távolságra feleannyi hőmennyiség jut ki az izzítás hevéből, mint 1 méter távolságra; a különbség a rúd második méterén hül ki a levegőbe.

Ugyanennek a természetes, de fontos felismerésnek egy másik, szemléletes megfogalmazását adjuk a következő módon: Tegyük fel, hogy odakint mínusz 15 fok van, és mi erőteljes fütéssel plusz 25 fokos hőmérsékletet tartunk egy kis épületben. Ha 35 fokra akarjuk növelni a benti hőmérsékletet, akkor (mivel a hömérséklet-különbséget 25\%-kal növelnénk) 25\%-kal több tüzelöre lenne szükségünk. Viszont ha nem növelnénk a tüzelö mennyiségét, de minden oldalról 25\%kal vastagabbak lennének a falak, akkor a hőmérsékletek különbsége is 25\%-kal több lenne, tehát bent ugyanúgy 35 fokot érhetnénk el. Vagy ha megelégednénk 
a 25 fokos benti meleggel, akkor 20\%-os energiamegtakarításra jutnánk 25\%-os falvastagítással.

A Pallas így ír: „Említésre méltó Fourier teoriája a hőközlésről; ezen problémát már előtte megoldotta ugyan Lambert, de csak vékony fémlemezekre nézve, három méret szerint kiterjedő testekre nézve csak Fourier-nek sikerült a feladat megfejtése. Fourier a hővezetés problémájának általános tárgyalására oly analitikai segédeszközt teremtett, mely azóta a fizikában a legnagyobb fontossággal bír és számos feladat megfejtésére szolgál."

\section{A FOURIER-ANALÍZIS KEZDETEI}

Fourier legismertebb munkájában (amely a merev testekben való hőterjedésről szól, és néhány évvel később jelent meg) találunk egy sort, mely a következő alakban tekint egy általános függvényt:

$\mathrm{f}(y)=a \cos (\pi y / 2)+a^{\prime} \cos (3 \pi y / 2)+a^{\prime \prime} \cos (5 \pi y / 2)+\ldots$.

Itt az összeg végtelenül folytatandó a $\pi y / 2$ szög páratlan egész számszorosainak mindegyikére, egy-egy alkalmas együtthatóval ellátva a koszinuszt. Bár Fourier korában mások is foglalkoztak már trigonometrikus függvények végtelen összegsoraival, de Fourier volt az első, aki lényegében minden, a gyakorlat szempontjából fontos függvényre kimondta az ilyen sorba fejthetőségnek a lehetőségét.

A mai kor kényesebb igényeinek megfelelően precízebben fogalmazzuk újra Fourier alapvető észrevételét: $\mathrm{Az} \mathrm{f}(x)$ valós szám értékü függvény legyen folytonos a 0 és 1 közötti $x$-ekre, és tegyük fel, hogy $0^{+}$-ban és $1^{-}$-ban is van véges határérték. Ekkor vannak olyan $\mathrm{a}_{1}, \mathrm{a}_{3}, \mathrm{a}_{5}, \ldots$ valós szám konstansok, melyekre tetszőleges 0 és 1 közötti $x$-re fennáll, hogy

$\mathrm{f}(x)=\mathrm{a}_{1} \cos (\pi x / 2)+\mathrm{a}_{3} \cos (3 \pi x / 2)+\mathrm{a}_{5} \cos (5 \pi x / 2)+\ldots$.

Az f függvény ismeretében integrálással lehet meghatározni az $\mathrm{a}_{1}, \mathrm{a}_{3}, \mathrm{a}_{5}, \ldots$ számokat. Például az a szám az a paraméternek az az értéke, amelyre 0 és 1 között az $\mathrm{f}(x)-a \cos (\pi x / 2)$

függvény négyzetének az integrálja a lehető legkisebb, az a 3 szám az a paraméternek az az értéke, amelyre 0 és 1 között az

$\mathrm{f}(x)-\mathrm{a}_{1} \cos (\pi x / 2)-a \cos (3 \pi x / 2)$

függvény négyzetének az integrálja a lehető legkisebb, az a $\mathrm{a}_{5}$ szám az a paraméternek az az értéke, amelyre 0 és 1 között az

$\mathrm{f}(x)-\mathrm{a}_{1} \cos (\pi x / 2)-\mathrm{a}_{3} \cos (3 \pi x / 2)-a \cos (5 \pi x / 2)$ 
függvény négyzetének az integrálja a lehető legkisebb, és így tovább. Kis számolás után hamar kiderül, hogy minden $n$ pozitív páratlan számra $a_{n}$ értéke megegyezik a

$2 \mathrm{f}(x) \cos (n \pi x / 2)$

szorzatfüggvény 0 és 1 közötti integráljával. Például az $1-x^{2}$ függvény esetében azt kapjuk, hogy $\mathrm{a}_{1}$ értéke körülbelül 1,032, $\mathrm{a}_{2}$ értéke körülbelül -0,038224, $\mathrm{a}_{3}$ értéke körülbelül 0,008264. Érdemes összehasonlítani 0 és 1 között az $1-x^{2}$ függvényt és az

$1,032 \cos (\pi x / 2)-0,038224 \cos (3 \pi x / 2)+0,008264 \cos (5 \pi x / 2)$

függvényt. Szabad szemmel nem is látható különbség a két függvénygörbe között. Ha az egyik függvényből kivonjuk a másikat, akkor a 2. ábrán látható függvénygrafikont nyerjük.

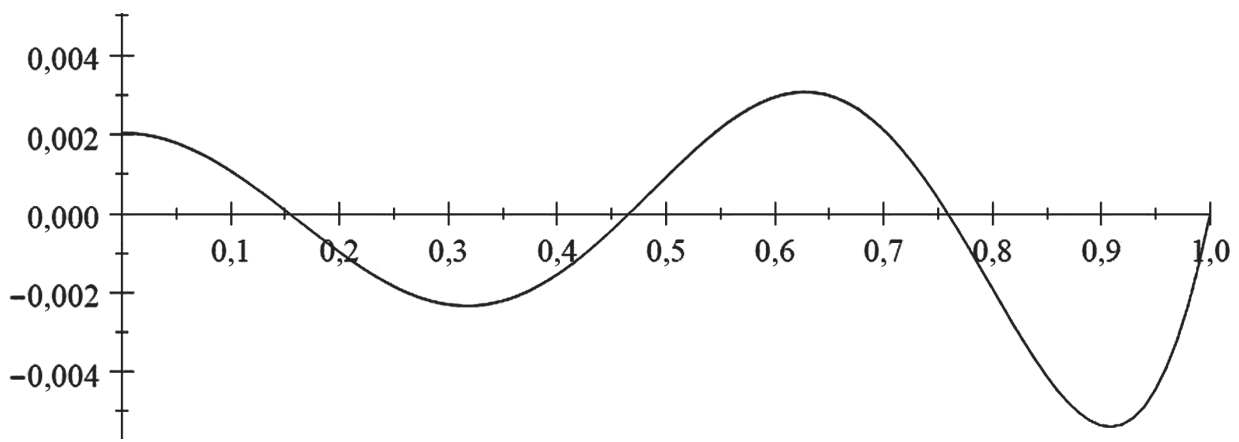

2. ábra. Egy Fourier-sor egyik közelítő összegének hibája

Scientific Workplace (Version 5.5) 30 napig ingyenes változatának felhasználásával készítette Hujter Mihály, 2018 (https://www.mackichan.com/)

Látható, hogy a két függvény közti eltérés még az 5 ezredet sem éri el, átlagosan pedig csak 1 ezred nagyságrendủ. Feltűnően jó közelítés, pedig csak három koszinuszfüggvényt használtunk! Ez a példa jól mutatja a Fourier-féle felismerés hasznát: tetszőleges folytonos függvény néhány trigonometrikus függvény segítségével nagyon jól approximálható. A megfelelö együtthatók kiszámításához csak integrálásokra van szükség. Ha esetleg az eredeti függvény bonyolultsága okán számítási nehézségek lépnének fel, akkor közelítő számítások eredményei is jól felhasználhatók.

Napjainkra Fourier eredeti felfedezéséből egy egész elmélet nőtt ki: a Fourier-analízis. A gyakorlati hasznok közül csak néhányat említünk: hanganyagok .mp3 tömörítése, képek .jpg tömörítése, beszéd- és zeneszerszám-szintetizátorok készítése, orvosi röntgenképek élesítése, távoli galaxisok és bolygók felderítése. 


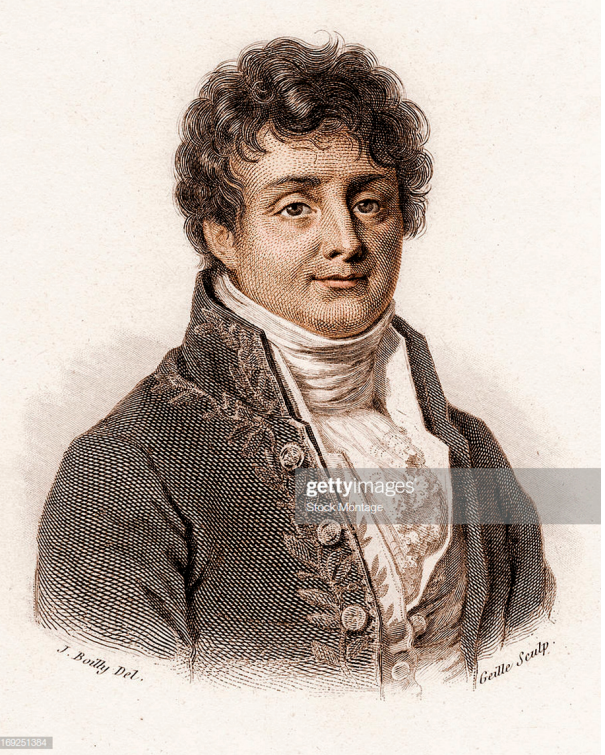

3. ábra. Fourier, a tudós hivatalnok, Louis Léopold Boilly metszete, https://hu.wikipedia.org/wiki/Joseph Fourier\#/media/File:Fourier2.jpg (közkincs)
Meg kell említenünk, hogy a Fourier-analízis kifejlesztéséhez fontos hozzájárulása volt a huszadik század legelejétől Fejér Lipótnak és Riesz Frigyesnek, és később az ő tanítványaiknak. Ezekröl a kapcsolatokról Vekerdi László (2014) írásaiban sokat olvashatunk. Ajánljuk még Tandori Károly (1980) tanulmányát is.

\section{FOURIER ÉLETÉNEK UTOLSÓ ÉVEI}

Térjünk vissza Fourier életéhez! Odáig követtük, hogy inkább kitért az excsászár útjából. Ezt azért érezhette szükségesnek, mert miközben Bonaparte kényszerből Elba szigetén időzött, Fourier hivatalában maradt még XVIII. Lajos trónra kerülésekor is. Aztán Napóleon végleg elbukott, és Fourier is elvesztette az állását és a jól megérdemelt nyugdíját is. A Napóleon idején kiérdemelt bárói ranggal járó illetmény is elapadt. Nehéz helyzetében Fourier még azt is fontolgatta, hogy Angliába költözik. Egy volt tanítványa segítette hozzá, hogy a Statisztikai Hivatal vezetője lehessen. A fizetés csekély volt ugyan, de Fourier most már sokadszorra megmenekült nehéz élethelyzetéből. Adminisztratív hatalma nem maradt, de legalább oktatói és tudományos kutatói tevékenységét folytathatta.

Fourier-nek ,szabad akadémikus" tagságot szavaztak 1816-ban. Sokat publikált ezekben az években. Itt most csak két matematikai eredményét emeljük ki. Az egyik, amelyben a René Descartes által már két évszázaddal korábban megtalált és Fourier előtt néhány évtizeddel Segner János András által részben bizonyított algebrai tétel továbbfejlesztéséről van szó. Egy magas fokú polinomegyenlet valós szám megoldásainak darabszámát szeretnénk előre jelezni egy adott intervallumban. De sokkal-sokkal kevesebb számolást akarunk végezni, mint amennyit a gyökök egyenkénti, Newton-módszer szerinti aprólékos közelítő letapogatása jelentene. Fourier észrevétele alapján elegendő a polinom értékét, a polinom deriváltját, annak a deriváltját, annak a deriváltját és így tovább kiszámítani az előre adott intervallum végpontjaiban. (Például egy nyolcadfokú polinom révén adott egyenlet esetében 2-szer 8+1 számot kapunk.) A kiszámított két számsorozat mindegyikét elképzelve a számegyenesen lépkedjünk rajtuk sor- 
ban, és jegyezzük meg, hogy hányszor lépünk át az origó felett! (Nyolcadfokú polinom esetében ez a darabszám $0,1,2,3,4,5,6,7,8$ bármelyike lehet.) Az intervallum két végpontjára kapott egy-egy darabszám különbsége éppen anynyi, ahány megoldása az eredeti polinomegyenletnek volt, vagy 2-vel több, vagy 4-gyel, vagy 6-tal és így tovább. A különbség mindenképpen egy nemnegatív páros szám. A további részletek iránt érdeklődő olvasóknak ajánljuk Szirmai Csilla (2018) közelmúltban megvédett szakdolgozatát.

Egy másik terület, ahol Fourier alapvető eredményeket ért el, az a napjainkban operációkutatás néven ismert alkalmazott matematikai tudományág. Az ide tartozó eredményekről Fourier és Motzkin tétele, illetve Farkas Gyula lemmája néven nyerhetünk információt.

Fourier 1830. május 16-án hunyt el Párizsban; addigra az Egyiptomban szerzett trópusi betegségek teljesen felörölték a szervezetét. Tudományos nagyságát csak az ezredforduló környékén kezdte igazán felismerni az emberiség. A globális felmelegedés egyik fö okaként emlegetett üvegházhatásról kevesen tudják, hogy az is Fourier felfedezése két évszázaddal ezelőttről.

\section{FOURIER EMLÉKEZETES MONDÁSAI}

Írásunkat néhány érdekes Fourier-idézettel zárjuk. Köszönettel tartozunk Károlyi Katalin kolléganőnknek, aki a fordítások pontosításában segédkezett.

A természettudományok hátteréül szolgáló matematikáról Fourier így vélekedett: „Nincs oly más nyelv, amely egyetemesebb és egyszerübb, hibáktól és homályosságtól mentesebb, azaz méltóbb lenne arra, hogy a természeti lények állandó kapcsolatait kifejezze."

„A matematikai analízis minden jelenség tanulmányozásánál ugyanazzal a nyelvvel interpretálja a jelenségeket, mintegy tanúsítva a világegyetem tervének egységét és egyszerüségét, még nyilvánvalóbbá téve az összes természeti ok fölött uralkodó örök rendet."

A hő áramlásával kapcsolatban így ír Fourier: „A hő, akár a nehézkedés, a világegyetem minden alkotórészébe behatol, sugarai a tér minden részét betöltik. Munkánk célja az, hogy ennek matematikai törvényeit leírjuk."

A természet tanulmányozásáról általában pedig ez a véleménye: „Az alapvető okok számunkra ismeretlenek, azonban egyszerü és állandó törvényeknek engedelmeskednek, mely törvények a megfigyelés által feltárhatók, $\mathrm{s}$ tanulmányozásuk a természeti filozófia feladata." 


\section{IRODALOM}

História Tudósnaptár, 2018: Fourier, http://tudosnaptar.kfki.hu/historia/egyen.php?namenev= fourier

Pallas - Bokor J. (szerk.) (1897): A Pallas nagy lexikona. Pallas Irodalmi és Nyomdai Rt., http:// mek.oszk.hu/00000/00060/; legújabb kiadás: Bokor József (szerk.): A Pallas nagy lexikona. Arcanum: FolioNET (1893-1897, 1998)

Szirmai Cs. (2018): Budan és Fourier tétele a valós polinomok gyökeiről. BSc szakdolgozat, BME Matematikus szak, http://math.bme.hu/ hujter/szirmai.pdf

Tandori K. (1980): Fejér Lipót. Magyar Tudomány, 4, 271-279.

Vekerdi L.- Gazda I. (szerk.) (2014): Vekerdi László matematikatörténeti írásaiból. Budapest: Magyar Tudománytörténeti Intézet, http://vekerdi.tudomanytortenet.hu/

URL1: http://math.bme.hu/ hujter/fourier.jpg 